Canadian Journal of Family and Youth, 10(2), 2018, pp 1-5

ISSN 1718-9748 (C) University of Alberta

http://ejournals.library.ualberta.ca/index/php/cjfy

\title{
Method as Process, Process as Method
}

\section{A Publication from the Inaugural Institute for Child and Youth Studies Symposium - At the Intersections of Childhood 2017: Digital, Indigenous, and Youth Issues, April 2017}

\author{
Victoria Holec and Amy Mack
}

Victoria Holec is a PhD Student in Cultural, Social, and Political Thought and is a Graduate Assistant for the Institute for Child and Youth Studies at the University of Lethbridge. She is an interdisciplinary scholar working at the intersections of youth, digital methods, discourse, and poststructuralism. Her $\mathrm{PhD}$ research examines Millennial identities as both other-constructed and self-performed through discourse and lived experience. She questions the usefulness of the generation as a category of analysis. Victoria is particularly interested in conceptualizations of post-identity and adopts a poststructuralist lens in critically examining these. She further explores the generation in the demographic sense as well as in the relational or processual sense. Her work examines microblog discourses about and by Millennials. She utilizes contemporary digital and qualitative methods. Her background is methodfocussed in both quantitative and qualitative analyses (BA Psychology, UBC; MSc Neuroscience, University of Lethbridge). She has further worked professionally in the fields of education, health sciences, management, statistics, and applied research. Her research interests include millennials, generations, identity, selfhood, GenY, GenX, GenZ, youth, technology, communication, culture, self-perception, identity performance, identity construction, media, microblog, postmodernism, poststructuralism, data analysis, statistics, phenomenography, and mixed-method designs. Major publications include Holec, V. \& Marynowski, R. (2017, forthcoming). Does it matter where you teach? Insights from a quasi-experimental study on student engagement in an active learning classroom. Paper under review at Teaching \& Learning Inquiry (Sep 2017); Holec, V. \& Whishaw, I. Q. (2015). Neural basis of hypnosis. In Wright, J. D. (Ed.) International Encyclopedia of Social and Behavioral Sciences, $2^{\text {nd }}$ ed., 465-471; and Holec, V., Pirot, H. L., \& Euston, D. R. (2014). Not all effort is equal: The role of the anterior cingulate cortex in different forms of effort-reward decisions. Frontiers in Behavioral Neuroscience, 8(12), 1-17. doi: 10.3389/fnbeh.2014.00012

Amy Mack is a doctoral student with the Department of Anthropology at the University of Alberta. She is a settler scholar from Niitsitapi (Blackfoot), Nakoda (Stoney), and Tsuut'ina territory (Treaty 7). She currently resides in Cree, Saulteaux, Niitsitapi, Métis, and Nakota Sioux territory (Treaty 6). Her research interests include the intersection of youth, technology and the Canadian North. In her current research project, she explores how Indigenous and settler young people navigate digital technologies designed to promote cultural resilience and technical capacity within the context of limited Internet infrastructure in the Northwest Territories. Major publications include Alexander, K., Eagle Bear, H., Heavy Runner, T., Henrickson, A., Little Mustache, T., Mack, A., Newberry, J., Pace-Cross-Child, T., Spring, E., and Weaver, K. (Under review, 2017); Translating encounters and challenging settler colonialism: How a transmedia project connects Indigenous young people with higher education.” Submitted to the Journal of Community Engagement and Higher Education; and Alexander, K., Mack, A., Newberry, J., \& Spring, E. (2016). Raising spirit and decolonizing methods. NEOS, 8(2): 5-6. Retrieved from http://acyig.americananthro.org/ 
Editorial Introduction

\section{Introduction}

This publication is the culmination of an interdisciplinary, collaborative effort to explore the intersections of digital, Indigenous, and youth issues. These issues were selected in response to the Social Science and Humanities Research Council (SSHRC, 2017) call of Canada's future challenge areas, which articulate a need for research in Indigenous experiences and emergent technologies. Moreover, there is an ever-present need for research on the experience of young people, particularly at the intersection of education and real-world experiences.

To facilitate this discussion, a two-day symposium, 'At the Intersections of Childhood: Digital, Indigenous, Youth Issues,' was held by the Institute for Child and Youth Studies (ICYS) at the University of Lethbridge in April 2017. Scholars working in the fields of anthropology, education, English, history, Indigenous studies, new media and social justice met with draft papers in hand and collectively created a space for discussion and workshopping of these issues as they related to their own and each other's work. The following day, these draft papers, peppered with insights and comments from the prior discussion, were presented to a community, student and academic audience in form of a keynote address followed by three panels, each focussing on one aspect of the symposium (i.e. digital, Indigenous or youth issues). The discussion was thus removed from a strictly academic realm and opened to critique and questions from an inclusive audience which involved community youth and Indigenous participants. The work conducted by participating panelists was also far from strictly academic; rather, it was tangible and meaningful for the communities, and in particular the youth, who were involved in the various projects. In fact, many projects were created with the specific goal of opening dialogue between communities and academia and addressing community needs. What 
you will find in this collection are these workshopped papers, reviewed by all of us, and critiqued and commented upon by the communities that they are accountable to.

\section{Unsettling Method Through Process}

In creating the space for such dialogue at the intersections of a) digital, Indigenous and youth issues and b) community and academia, a prominent theme emerged which was centred on the process of research with youth. This inspired the theme of this publication, Method as Process, Process as Method, diverting the emphasis away from the products of research as the ultimate end and towards the role of the research process itself. In realizing that process is what teaches us as researchers about youth in a raw and powerful way, we as researchers can take a more detailed look at our methods to identify how youth may shape the process that overthrows neatly planned ideas for research, thereby recognizing this process as co-production. Such coproduction can in turn inform and enrich our researcher-centric investigation by letting it unsettle us through upheaval of expectations and decentering of presuppositions. Often, youth do not have the opportunity to co-create research. Their agency and capacity are not always recognized nor elicited. The article by Erin Spring and Andrea Fox as well as that by Amy Mack and Jan Newberry highlight process as a method to recognize the voice of Indigenous youth and to acknowledge their research contributions. In letting youth define their own identity (Spring \& Fox) and in allowing youth to be para-ethnographers (Mack \& Newberry), their respective research methods centre youth in the research as co-creators. In the case of Mack and Newberry, incorporating youth meant relinquishing much of their control over the research process.

\section{Visualizing the Process: Examining Youth Refusal}

In discussing process, the question surfaced about how to realize or visualize this process, especially if it involves not only the researcher, but also community and youth. Daniela Navia 
and Chelsey Hauge look more closely at the difficulty of realizing the process, especially when youth refuse to be part of any emerging product. While we may not be able to capture youth resistance as an outcome, the process of their refusal can still influence our method and results. Moreover, while we may not be able to make visible this process, we can learn from it for our future methods. Daniela Navia’s article highlights how the process of making art was more important to youth than the need to present or talk about it, which is often the focus of academic discourse. Thus, though our methods may plan for youth to be part of the process we must graciously accept their decision to conclude their role when they see fit. Moreover, we cannot assume youth require a researcher to 'give' them a voice and instead listen to the unvoiced power of youth refusal. As researchers, we tend to be outcome-focussed, thereby neglecting what the process can teach us. As Chelsey Hauge writes in her article, it can be easy to miss the wealth of value the process brings when we curtail our view to the narrow lens imposed by the end result. Chelsey was able to see youth asking productive questions and embarking on the creative process, although these aspects were somewhat lost in the end result of the media literacy and civic engagement youth program in Nicaragua.

\section{Process is Ephemeral and Situated in Liminality}

Another aspect that makes process difficult to capture is its intrinsically transient nature. Process is not what we usually value in our method, which is typically aimed at the stable and recordable. Process instead is often dynamic and ephemeral, emerging out of the liminal space where we leave the safe confines of method but have not yet entered the finality of product. Process is risky. Kirsten Lindquist helps youth navigate their own processes and stories. Her work is a process too, a "living document," something that is fleeting and changing, which is evident in this publication. Process, because of its dynamic and emergent nature brings to the 
Editorial Introduction

surface exchanges and transactions, but it can also call attention to, while not completely remove, the liminality in which youth are sometimes situated. Michelle Hogue and Joanne Forrest highlight the strong relationship- and capacity-building that can emerge and blossom from process in spite of its transient nature.

\section{Intersections}

We present here the beginning of what we hope to be an ongoing conversation in academia and beyond about the way we can reconceptualize method with emphasis on its process rather than product, and how process can be re-thought as influencing, creating and questioning method. Each of these papers begins by considering how process emerged from method in the respective projects through some form of artistic expression or visual realization of the process. These papers also highlight how youth voice, which is traditionally discounted, stands at the centre of the work conducted, and is particularly loud in its refusal. Finally, these papers explore the transient nature of process, which requires effort and time to visualize, but can still be fruitful in co-creating relationships and transactions typically located in liminality. In working through these intersections of digital, Indigenous and youth issues, we realized that it is

hard, exhausting, always incomplete and ongoing work to question method and process and their reciprocal relationship. We invite the reader to do this for the articles in this collection. 